\title{
REGIONAL SENSITIVITY OF THE TESTICULAR ARTERY TO NORADRENALINE IN RAM, RABBIT, RAT AND BOAR
}

\author{
G. M. H. WAITES, VIGTORIA ARCHER AND G. A. LANGFORD* \\ Department of Physiology $\&$ Biochemistry, University of Reading, \\ Whiteknights, Reading RG6 $2 A \mathcal{J}$
}

(Received 6th February 1975)

The testicular artery of mammals with scrotal testes is long and either coiled or with multiple branches. The pampiniform venous plexus closely surrounds the artery forming a counter-current heat exchange system (Harrison \& Weiner, 1949; Dahl \& Herrick, 1959; Waites \& Moule, 1961) and the length of the artery attenuates the pulse pressure (Waites \& Moule, 1960; Setchell \& Waites, 1969; see also review by Setchell, 1970).

Unlike the proximal testicular artery, the distal portion of the artery within the testicular capsule in the ram has a thinner wall with less muscle, collagen and elastin, and a wide-bore, elliptical lumen. The only functional significance yet ascribed to the unusual structure of the capsular testicular artery is the induction of a non-pulsatile blood flow through the testis (Waites \& Moule, 1960).

The testicular microcirculation responds like other vasculature to adrenaline and noradrenaline (Setchell et al., 1966) and to serotonin (Kormano et al., 1968), but is very sensitive to cadmium (Parizek, 1960; Waites \& Setchell, 1966) and relatively insensitive to temperature (Waites \& Setchell, 1964; see Setchell, 1970). The hormonal environment of the testicular blood vessels is special since they are surrounded by interstitial fluid rich in androgens. It was of interest, therefore, to know if the unusual structure and environment of the capsular testicular artery had altered its response to hormonal influences.

An almost universal characteristic of vascular smooth muscle elsewhere in the body is its capacity to constrict when $\alpha$-receptors are stimulated by noradrenaline released from sympathetic post-ganglionic neurones. We have therefore compared the constriction of the central ear artery to catecholamines with the vasoconstriction of portions of the testicular artery.

Short lengths $(1$ to $2 \mathrm{~cm})$ were dissected from the following arteries: the central artery of the ear of ram and rabbit; the proximal testicular artery; the capsular testicular artery of ram, rabbit, rat and boar; the artery supplying the corpus epididymidis of the ram. The tissue was collected from nine rams and one boar, either at the abattoir immediately after death or during anaesthesia with halothane-nitrous oxide-oxygen after pentobarbitone sodium induction,

\footnotetext{
* Present address: Reproductive Physiology, Animal Research Institute, Department of Agriculture, Ottawa, Ontario, Canada.
} 
and from seven rabbits and three rats anaesthetized with urethane or halothaneair.

Care was taken not to stretch the artery, and the surrounding tissue was either left attached to the tunica adventitia or removed by careful dissection. A polyethylene (Portex Ltd, Hythe, Kent) cannula was tied into one end of the
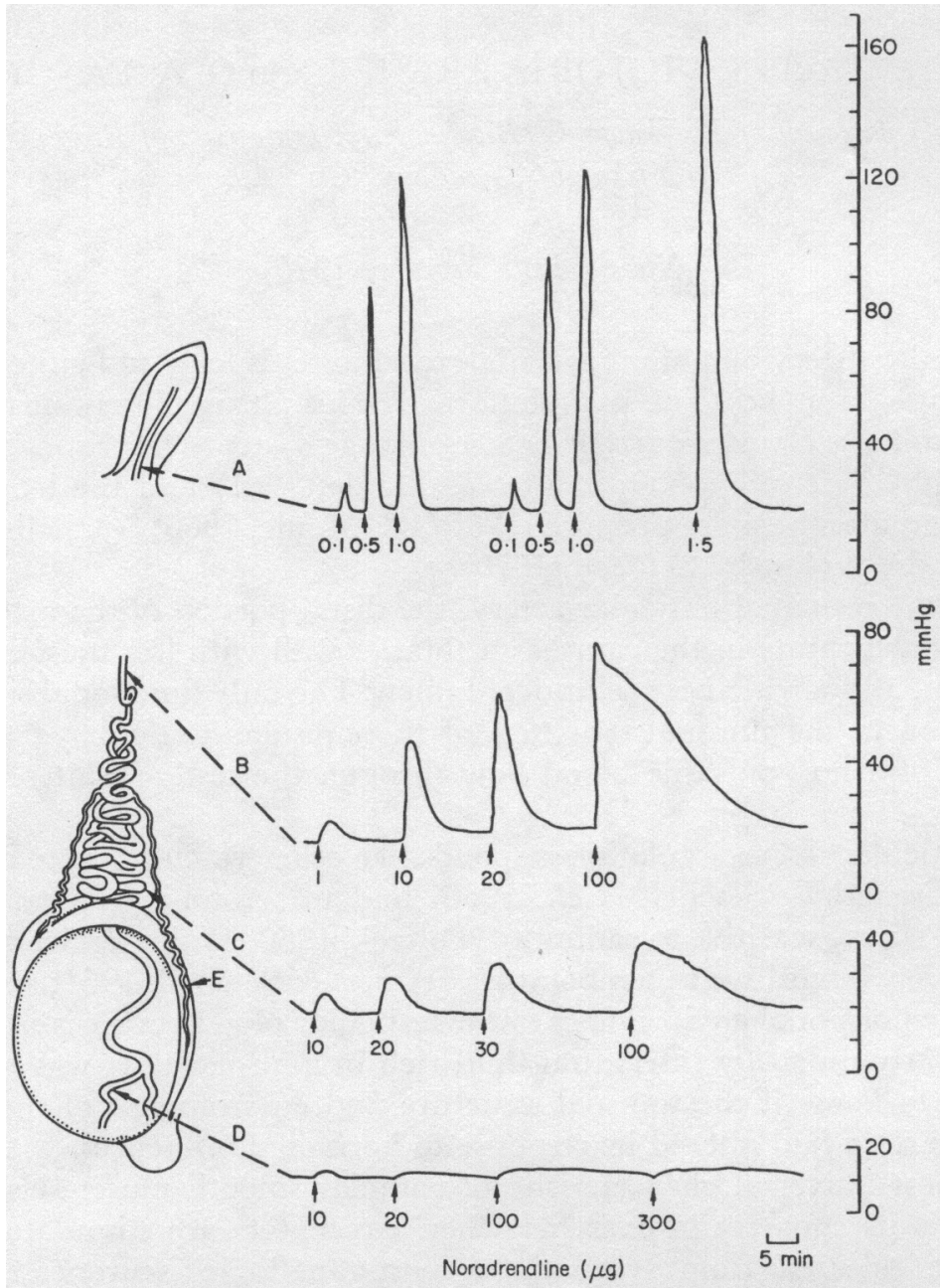

TExT-FIG. 1. Tracings of typical pressure responses obtained by adding noradrenaline to the isolated perfused segments of the central ear and testicular arteries of the ram. $A$, central ear artery; B, testicular artery above the spermatic cord; $C$, terminal coils of the testicular artery; $\mathbf{D}$, capsular testicular artery; $\mathbf{E}$, artery to the corpus epididymidis. Doses of noradrenaline were added at the arrows; perfusion flow rate was $6 \mathrm{ml} / \mathrm{min}$; temperature 33 to $34^{\circ} \mathrm{C}$; recording speed, $2 \mathrm{~mm} / \mathrm{min}$.

artery, through which oxygenated Krebs-bicarbonate fluid was pumped at a rate of $6 \mathrm{ml}, 12 \mathrm{ml}$ or $20 \mathrm{ml} / \mathrm{min}$ for ram arteries, $0.4 \mathrm{ml} / \mathrm{min}$ for rabbit and rat, and $6 \mathrm{ml} / \mathrm{min}$ for boar arteries. It was found that a temperature of 26 to $39^{\circ} \mathrm{C}$ did not markedly affect the responses, and so the artery bath and all connecting tubes were surrounded by a water jacket at 33 to $34^{\circ} \mathrm{C}$. 
The noradrenaline (Winthrop Laboratories, Surbiton-on-Thames, Surrey) and adrenaline (Evans Medical Ltd, Speke, Liverpool) were diluted immediately before each experiment with saline containing $0.1 \mathrm{mg}$ ascorbic acid $/ \mathrm{ml}$; phentolamine (Rogitine: Ciba, Horsham, Sussex) was used from the ampoule.

The drugs were injected into the Krebs-bicarbonate perfusion fluid just proximal to the artery and exerted their action during one passage through the artery after which they passed into the organ bath and were quickly removed by overflow. When the artery constricted, the increase in perfusion pressure was transmitted to a mercury manometer and recorded on a kymograph by means of a pen attached to a float on the mercury surface.

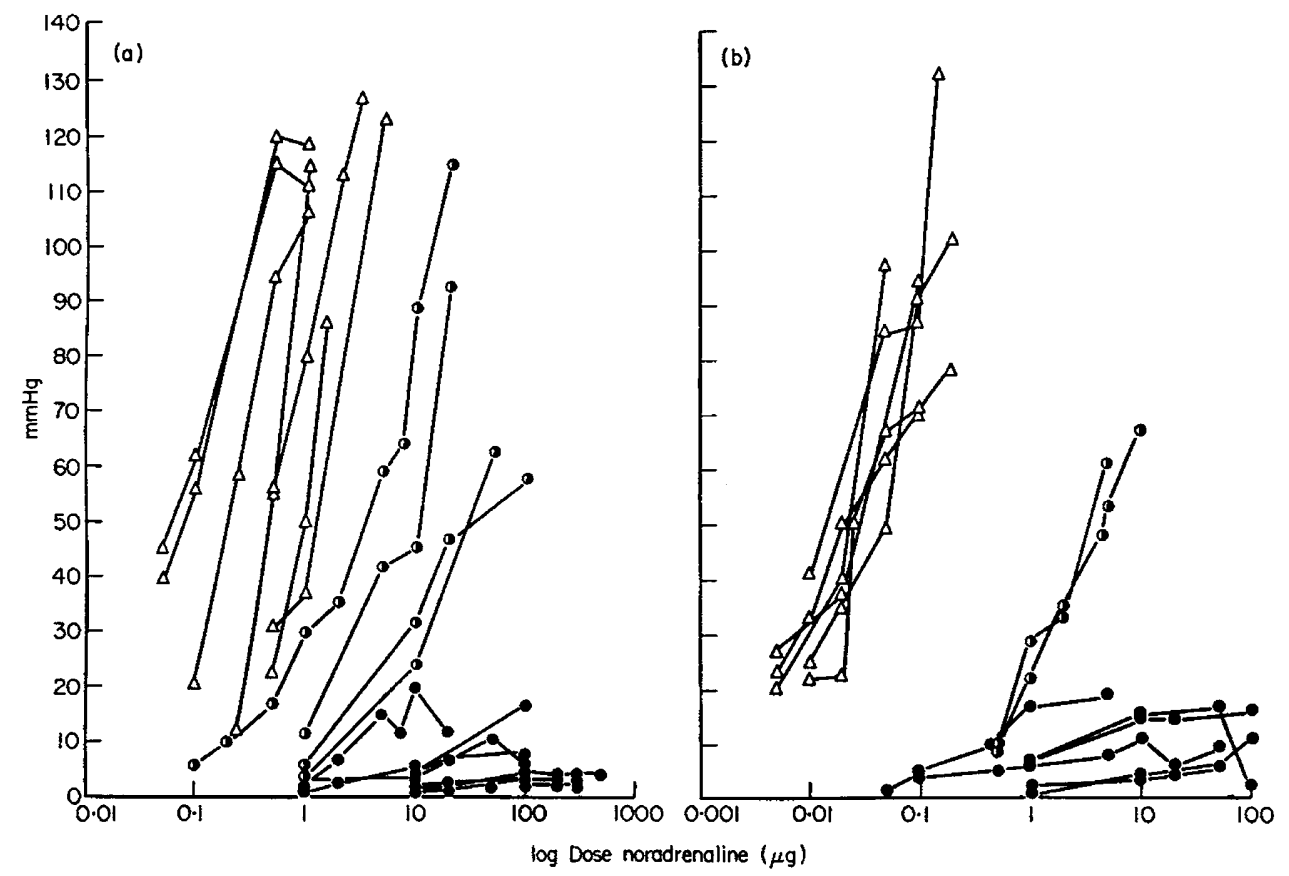

TEXT-FIG. 2. Relationship between increase of perfusion pressure and $\log$ dose of added noradrenaline for the central ear artery $(\Delta)$, testicular artery above the spermatic cord (o) and capsular testicular artery (e) of (a) ram and (b) rabbit. Each line joins the average of up to three tests at each dose for one artery.

Perfused segments of the central ear arteries of the rabbit and ram were sensitive to noradrenaline, giving linear dose-response curves with threshold responses to doses of between 0.005 and $0.1 \mu \mathrm{g}$ (Text-figs 1 and 2). The doseresponse curves obtained with portions of the testicular artery from above the spermatic cord (Text-fig. 1, B) were parallel to those of the ear arteries but the threshold doses were higher in both species. By contrast, the capsular testicular arteries (Text-fig. 1, D) of both species were relatively insensitive to noradrenaline; a much higher dose was needed to elicit a threshold response and the doseresponse curves were almost flat (Text-figs 1 and 2). Intermediate responses were obtained from a portion of the terminal coils of the artery before it entered the testicular capsule (Text-fig. 1, G). It was noticeable that, as the sensitivity 
of the different arteries decreased, the duration of the constriction increased and was greatest in the capsular arteries (Text-fig. 1).

The responses from the testicular arteries of rams were independent of perfusion flows of 6,12 or $20 \mathrm{ml} / \mathrm{min}$; there was a tendency for the responses from the capsular portions to be slightly greater at the higher flows but the difference between the regions of the artery was maintained. The relative insensitivity of the capsular testicular artery to noradrenaline was confirmed in three rats and one boar.

The dose-response curves of arteries supplying the corpus epididymidis of the ram (Text-fig. 1, G) were similar to those of the proximal testicular artery, and the threshold response to noradrenaline occurred at doses of between 0.1 and $1 \cdot 0 \mu \mathrm{g}$.

The capsular testicular artery of the ram and rabbit was insensitive to adrenaline at doses of up to $100 \mu \mathrm{g}$.

The constrictor responses from all the artery portions tested were abolished by adding $2 \mathrm{mg}$ phentolamine to the perfusate and allowing it to act for $30 \mathrm{sec}$ before continuing the perfusion. Phentolamine is an $\alpha$-receptor blocking drug, and this finding suggests that the vascular smooth muscle of the capsular testicular artery of the animals examined has many fewer $\alpha$-receptor sites than has smooth muscle of other regions of the same artery or the central ear artery.

In the ram, the response to noradrenaline decreased sharply between the terminal coils of the artery and the region where it entered the testicular capsule. As in the boar, the artery in the capsule divides into two arteries which then branch profusely before penetrating the parenchyma. In the rabbit and the rat the artery passes lengthwise round the testis before branching, encircling the testis in the rabbit and almost so in the rat (see Setchell, 1970). There are, therefore, extensive lengths of noradrenaline-insensitive artery in the testicular capsule of these animals. The absence of response is not due to a lack of smooth muscle, since the testicular artery retains a tunica media but of reduced thickness.

On morphological grounds, Schweizer (1929) suggested that the inflow of blood to the testis may be influenced by the testicular capsule exerting pressure against the underlying testicular parenchyma. In many animals, including those of the four species used in this study, the testicular capsule has been shown to undergo spontaneous contractions, or contractions induced by various autonomic agents (Davis \& Langford, 1969, 1970; G. A. Langford, unpublished observations), and it responds to spermatic nerve stimulation (Rikimaru \& Suzuki, 1972) by contraction of the smooth muscle fibres found in the capsule (Davis et al., 1970; Langford \& Heller, 1973). We now have evidence in the rabbit that testicular arterial perfusion pressure can be influenced by contractions of the testicular capsule (G. A. Langford, V. Archer and G. M. H. Waites, unpublished observations).

We wish to thank Mr A. H. Dickenson and Mr D. G. Eva for help with some of the experiments and the World Health Organization and Population Council of New York for grants. One of us (G.A.L.) was supported by the Medical Research Council of Canada. 


\section{REFERENCES}

DAHL, E.V. \& HeRrick, J.F. (1959) A vascular mechanism for maintaining testicular temperature by counter-current exchange. Surg. Gynec. Obstet. 108, 697-705.

Davis, J.R. \& LANGFord, G.A. (1969) Response of the testicular capsule of the rat to autonomic drugs. F. Reprod. Fert. 19, 595-598.

Davis, J.R. \& LANGroRd, G.A. (1970) Pharmacological studies on the testicular capsule in relation to sperm transport. In The Human Testis, pp. 495-514. Eds E. Rosemberg \& C. A. Paulsen. Plenum Press, New York.

Davis, J.R., Langford, G.A. \& Kirby, P.J. (1970) The testicular capsule. In The Testis, Vol. I, pp. 281-337. Eds A. D. Johnson, W. R. Gomes \& N. L. VanDemark. Academic Press, New York.

HARRISON, R.G. \& WEINER, J.S. (1949) Vascular patterns of the mammalian testis and their functional significance. F. exp. Biol. 26, 304-316.

Kormano, M., Karhunen, P. \& Kahanpaa, K. (1968) Effect of long-term 5-hydroxytryptamine treatment on the rat testis. Annls Med. exp. Biol. Fenn. 46, 474-478.

LANGFORD, G.A. \& Heller, C.G. (1973) Fine structure of muscle cells of the human testicular capsule: basis of testicular contractions. Science, $\mathcal{N}$.Y. 179, 573-575.

Parizek, J. (1960) Sterilization of the male by cadmium salts. F. Reprod. Fert. 1, 294-309.

Rikimaru, A. \& Suzuki, T. (1972) Mechanical responses of the isolated rabbit testis to electrical stimulation and to autonomic drugs. Tohoku 7. exp. Med. 108, 283-289.

Schweizer, R. (1929) Uber die Bedeutung der Vascularization, des Binnendruckes und der Zwischenzellen für die Biologie des Hodens. Z. Anat. EntwGesch. 89, 775-796.

Setchell, B.P. (1970) Testicular blood supply, lymphatic drainage and secretion of fluid. In The Testis, Vol. I, pp. 101-239. Eds A. D. Johnson, W. R. Gomes \& N. L. VanDemark. Academic Press, New York.

Setchell, B.P. \& Waites, G.M.H. (1969) Pulse attenuation and countercurrent heat exchange in the internal spermatic artery of some Australian marsupials. F. Reprod. Fert. 20, 165-169.

Setchell, B.P., Wartes, G.M.H. \& Thorburn, G.D. (1966) Blood flow in the testis of the conscious ram measured with ${ }^{85}$ krypton; effects of heat, catecholamines and acetyl choline. Circulation Res. 18, 755-765.

Wartes, G.M.H. \& Moule, G.R. (1960) Blood pressure in the internal spermatic artery of the ram. 7. Reprod. Fert. 1, 223-229.

WAITES, G.M.H. \& Moule, G.R. (1961) Relation of vascular heat, exchange to temperature regulation in the testis of the ram. F. Reprod. Fert. 2, 213-224.

WAites, G.M.H. \& SETChell, B.P. (1964) Effect of local heating on blood flow and metabolism in the testis of the conscious ram. F. Reprod. Fert. 9, 339-349.

Wartes, G.M.H. \& Setchell, B.P. (1966) Changes in blood flow and vascular permeability of the testis, epididymis and accessory reproductive organs of the rat after the administration of cadmium chloride. F. Endocr. 34, 329-342. 